\title{
Arquitectura foliar de las Lauraceae del Distrito Federal, Brasil, y nuevos patrones de venación propuestos
}

\section{Leaf venation of the Lauraceae of the Distrito Federal, Brazil, and new proposed venation patterns}

\author{
Kadja Milena Gomes-Bezerra, Lucia Helena Soares-Silva \& Sueli Maria Gomes \\ Universidade de Brasília, Departamento de Botánica, Casilla Postal 04457, CEP 70910-970 Brasília, DF, Brasil. \\ Isoares@unb.br
}

\begin{abstract}
RESUMEN
Fueron estudiadas las hojas de 18 especies de Lauraceae que crecen en el Distrito Federal (Brasil), con el objetivo de caracterizar sus patrones de venación e identificar características útiles en su diferenciación taxonómica, para que junto a su morfología se puedan obtener criterios útiles que ayuden en su identificación vegetativa. Las hojas fueron diafanizadas, coloreadas y fotografiadas. Los patrones de venación del segundo, tercero, cuarto y quinto orden fueron descritos e ilustrados para las especies estudiadas, que presentaron una venación secundaria de tipo broquidódroma o eucamptódromo-broquidódroma, excepto en Crytocarya aschersoniana y Ocotea aciphylla con venación broquidódroma promínula reticulada. La densidad de areolas se mostró como un buen carácter taxonómico, lo que no ocurrió con el número de lados que éstas poseen. Fueron propuestos los conceptos de nudos y ramas de las vénulas y criterios para la clasificación de sus ramificaciones. La mayoría de las especies poseen vénulas ramificadas. Los caracteres analizados, unidos con los morfológicos tales como tipo de indumento, formas de borde, y presencia y/o ausencia de domacios, posibilitaron la diferenciación de las 18 especies estudiadas, evidenciando la clara importancia de la arquitectura foliar en el reconocimiento taxonómico de especímenes en estado vegetativo.
\end{abstract}

Palabras clave: Arquitectura foliar, morfología de las hojas, venación foliar.

\begin{abstract}
Leaves of 18 species of Lauraceae that grow in the Distrito Federal (Brazil) were studied with the goal of characterizing their venation patterns and to identify useful traits in taxonomic differentiation, so that along with their morphology can be achieved concise criteria that help in vegetative identification. The leaves were cleared, stained and photographed. Venation patterns of second, third, fourth and fifth order were described and illustrated for the studied species, which showed brochidodromous or eucamptodromous-brochidodromous secondary venation pattern, except Cryptocarya aschersoniana and Ocotea aciphylla that presented brochidodromous prominulous-reticulate venation. Areole density was found to be a good taxonomic character, which did not happen with the number of sides that they have. The concepts of the venule nodes and branches and the criteria for the classification of its branches were proposed. Most species have branched venules. The analyzed characters together with the morphological ones, such as margin shape and presence or absence of domatia, allowed the differentiation of the studied species, demonstrating the clear importance of leaf architecture in the taxonomic recognition of specimens in a vegetative state.
\end{abstract}

KEYwords: Leaf architecture, leaf morphology, leaf venation.

\section{INTRODUCCIÓN}

La familia Lauraceae Juss. agrupa cerca de 50 géneros y entre 2.500 y 3.000 especies (Van der Werff \& Richter 1996), separadas en dos subfamilias, Cassythoideae Burnett, que es monotípica con un único género Cassytha (todas parásitas), y Lauroideae Burnett que está representada por árboles y arbustos (Judd et al. 1999). En Brasil estan presentes 25 géneros y aproximadamente 400 especies (Souza \& Lorenzi 2005). Para el Distrito Federal son citados 11 géneros y 36 especies (Proença et al. 2001), por lo cual es una de las familias más representativas, tanto en la flora como en la 
vegetación regional (Silva Júnior et al. 2001, Mendonça et al. 2008).

Todas las especies de Lauraceae son consideradas como taxonómicamente complejas, puesto que su identificación se torna difícil incluso hasta con material fértil (Vicentini et al. 1999, Quinet 2005), ya que las diferentes circunscripciones de los géneros requieren de una gran cantidad de caracteres morfológicos reproductivos y vegetativos (Raj \& Van der Werff 1988, Christophel et al. 1996, Moraes \& Paoli 1999). Es en este sentido que los estudios micromorfológicos pueden proporcionar contribuciones importantes. La ausencia de estructuras reproductivas en las exsicatas, de estudios florísticos y fitosociológicos, dificulta muchas veces la identificación taxonómica correcta de los especímenes de Lauraceae, por ejemplo especies de los géneros Endlicheria, Rhodostemonodaphne y la mayoría de las Ocotea son dioicas, por lo que especímenes con flores pistiladas o con frutos son difíciles de ser identificados (Vicentini et al. 1999). La generación de datos sobre la arquitectura foliar de las especies de esta familia pueden traer importantes aportes en su diferenciación taxonómica.

Entre los trabajos que analizaron la micromorfología foliar en Lauraceae, específicamente de los patrones de venación, se destacan los de Coe-Teixeira (1980), que fue exitosa en la separación de las especies del género Ocotea del Estado de São Paulo, utilizando caracteres morfológicos, además de la arquitectura foliar. Klucking (1987) realizó uno estudio de los patrones de venación en 564 especies en 31 géneros de esta familia. Cheng-Hong \& Ze-Lian (1991) analizaron y distinguieron 81 especies en 9 géneros de un bosque tropical en China utilizando caracteres del patrón de venación, y Moraes \& Paoli (1999) describieron las características de la epidermis y el patrón de venación de los nomofilos y eofilos de Cryptocarya moschata, Endlicheria paniculata y Ocotea catharinensis para fines taxonómicos.

El presente trabajo tuvo como objetivo analizar la arquitectura foliar de 18 especies de Lauraceae que ocurren en el Distrito Federal, con el fin de contribuir a la diferenciación taxonómica de esta familia.

\section{MATERIALES Y MÉTODOS}

Se estudiaron 18 especies de la familia Lauraceae seleccionadas a partir de la lista preliminar de la flora del Distrito Federal (DF), Brasil (Proença et al. 2001), de modo que se representó a tres tribus de la familia (Cryptocaryeae, Laureae y Perseeae, sensu Kostermans 1957), y considerando la disponibilidad de especímenes herborizados depositados en los herbarios UB, HEPH e IBGE (siglas según Holmgren et al. 1990). La Figura 1 muestra la ubicación del Distrito Federal en Brasil.

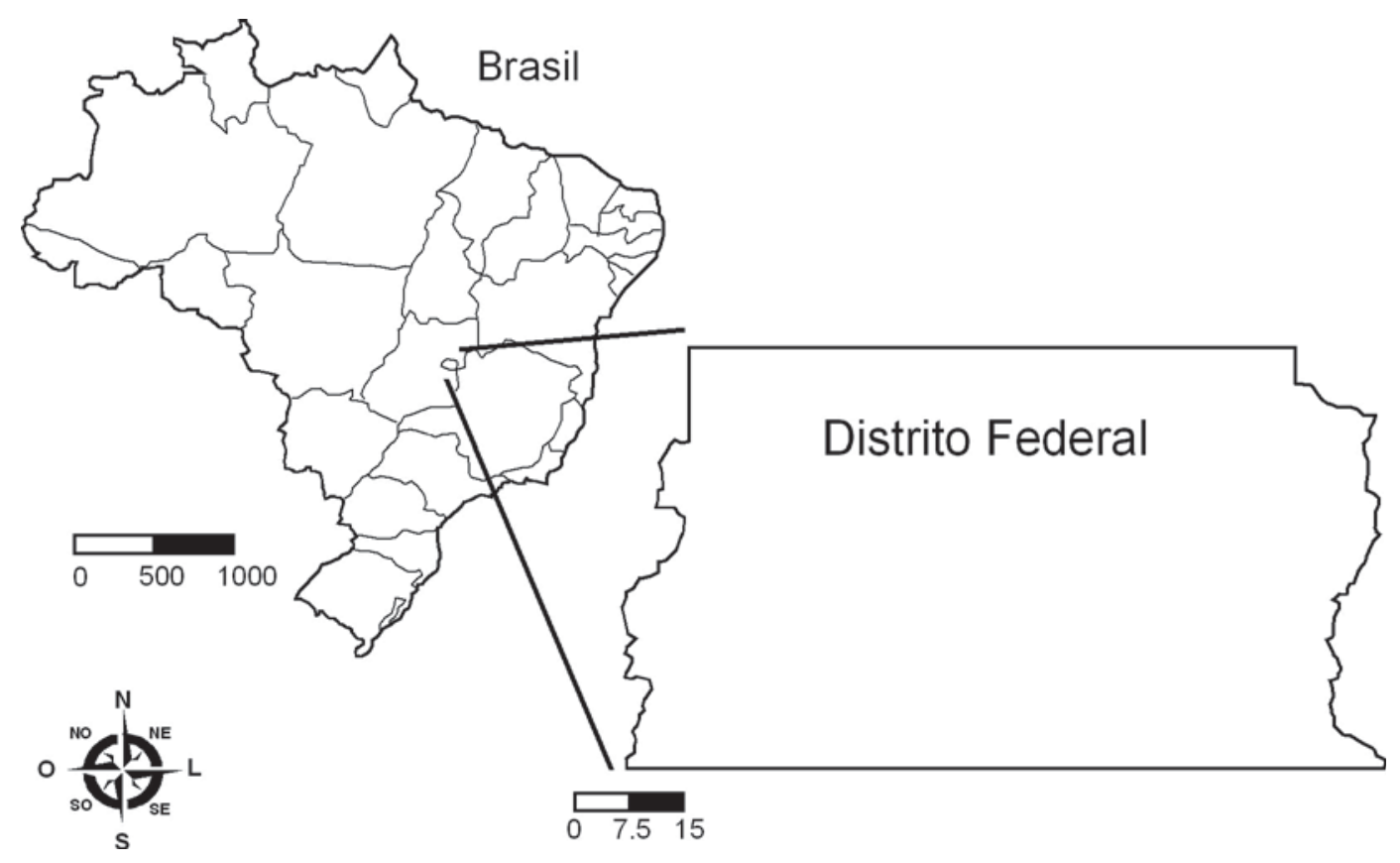

Figura 1. Localización del Distrito Federal, Brasil.

FIgURE 1. Localization of Distrito Federal, Brazil. 
Las especies y exsicatas estudiadas fueron: Aniba desertorum, Heringer 716 (IBGE); A. heringeri, Heringer 17662 (IBGE); Cryptocarya aschersoniana, Ratter 3887 (UB); Endlicheria paniculata, Pires 9235 (UB); Mezilaurus crassiramea, Miranda 1105 (UB); Nectandra cissiflora, Heringer 8380 (UB); N. hihua, Heringer 4817 (IBGE); $N$. turbacensis, Alvarenga 851 (IBGE); N. warmingii, Heringer 17572 (IBGE); Ocotea aciphylla, Heringer 9089 (UB); $O$. corymbosa, Heringer 2993 (IBGE); O. densiflora, Filgueiras 1422 (IBGE); O. diospyrifolia, Pereira 2142 (IBGE); $O$. minarum, Irwin 22105 (UB); O. pomaderroides, Heringer 8934 (UB); O. pulchella, Irwin 15671 (UB); O. spixiana, Melo 740 (IBGE) y O. velloziana, Heringer 8928 (UB).

Dos de las especies fueron estudiadas a partir de recolecciones personales, con el siguiente nombre y numero de colección: Ocotea aciphylla, Bezerra 2 (UB) y O. spixiana, Bezerra 3 (UB).

Fueron escogidas y retiradas de 3 a 5 hojas totalmente expandidas, situadas entre el tercero y quinto nudo de las ramas montadas en las muestras de herbario de tres individuos de cada especie. Las hojas frescas obtenidas de las colecciones en campo fueron sumergidas en etanol al 70 $\%$, hasta conseguir la remoción parcial de los pigmentos, lo cual ocurrió entre las 12 y 24 horas. Las hojas herborizadas fueron hervidas en agua y rehidratadas por aproximadamente 4 horas. El material fue diafanizado conforme el método de Shobe \& Lersten (1967), modificado por Fernandes (2007), que consiste en limpiar las hojas con una esponja, agua destilada y detergente (ingrediente activo: sulfonato lineal alquil benceno), con el fin de eliminar el exceso de cera en la superficie foliar y acelerar el proceso de diafanización. Este procedimiento fue utilizado para el material fresco y el herborizado.

Las hojas fueron sometidas a una tinción con safranina y colocadas en placas de vidrio de 4 y $6 \mathrm{~mm}$ de espesor, y selladas con barniz vitral incoloro (Paiva et al. 2006) de GP Arts $^{\circledR}$.

El registro de los resultados fue realizado con una cámara digital Sony Cyber Shot, modelo W-55, de 7.2 Megapixels. Imágenes de las redes menores de las nervaduras y areolas del tercio mediano foliar fueron obtenidas en el fotomicroscopio Axioskop-Zeiss. Todas las imágenes fueron tratadas digitalmente a través del programa PhotoShop 7.0.1 (Adobe Systems Incorporated 2002).

Para el análisis y descripción de la venación foliar fueron utilizadas las definiciones básicas establecidas por Hickey (1974), y LAWG (1999), Anexo 1. Algunos términos fueron modificados de Hickey (1974), Anexo 1.

Los términos propuestos en este trabajo fueron: nudo de la areola: que consiste en el encuentro de dos o mas ramas; rama de la vénula: región de la vénula entre dos nudos o en su región terminal, comprendiendo cada ramificación de la vénula. También fueron definidos en este trabajo términos utilizados por Alvarez et al. (2006), ya que este autor utilizó la terminología sin dar la definición. Estos son: ramificación laxa: vénula con hasta cinco ramas y ramificación dendrítica: vénulas con más de cinco ramas.

Los caracteres más comunes entre las 18 especies estudiadas fueron agrupados en la descripción de la venación de Lauraceae del DF en el presenta trabajo, no siendo repetidas en las descripciones de las especies. Fue confeccionada una clave de identificación para las especies analizadas sobre la base de la morfología externa y la venación foliar.

\section{RESULTADOS}

Las hojas de las especies estudiadas tuvieron generalmente una consistencia coriácea, con margen plano (Fig. 2:9) a acentuadamente revoluto (Fig. 3:17), con tricomas simples. Todas presentan un patrón primario de venación de tipo pinnado con apenas una nervadura primaria.

El patrón secundario en general es broquidódromo (Fig. 2:2), con ocurrencia del tipo mixto eucamptódromobroquidódromo en pocas especies (Fig. 3:18). Las nervaduras secundarias, generalmente, tienen la superficie adaxial plana y la abaxial prominente, con oscilaciones en el número de pares: en la mayoría de las especies con 6-15 pares de nervaduras secundarias, excepto en Ocotea densiflora con 3-4 pares.

Se observan diferentes patrones del espacio entre las venas: espacios regulares fueron observados en la mitad de las especies; en las demás este carácter se presentó de la siguiente forma: irregulares en Aniba desertorum (Fig. 2:2), Cryptocarya aschersoniana (Fig. 2:10) y Mezilaurus crassiramea (Fig. 3:18); espacios crecientes en dirección al ápice foliar en A. heringeri (Fig. 2:6), Ocotea aciphylla (Fig. 5:38) y O. corymbosa (Fig. 5:42); y decreciente en dirección al ápice en Nectandra hihua (Fig. 4:26), O. minarum (Fig. 6:54) y O. pomaderroides (Fig. 6:58).

El ángulo de divergencia comúnmente es agudo $\left(60-70^{\circ}\right)$ en relación a la nervadura primaria (Fig. 2:4). Las nervaduras intersecundarias son exmediales en la mayoría de las especies (Fig. 4:28), o ausentes (Fig. 4:36). Las nervaduras terciarias son, en la mayoría de las especies, del tipo alterno-percurrentes (Fig. 2:4), pudiendo presentar el tipo opuesto-percurrentes (Fig. 5:48) o una mezcla entre estos dos tipos (Fig. 2:4). Las areolas están bien desarrolladas, con formas poligonales y conformadas por las nervaduras del cuarto y quinto orden (Fig. 2:3, 4). Las vénulas son simples (Fig. 5:39), ramificadas laxas (Fig. 2:7), ramificadas dendríticas (Fig. 5:43) o ausentes (Fig. 4:27). 
Clave para la identificación de especies de Lauraceae del Distrito Federal - Brasil, sobre la base de la morfología y ARQUITECTURA FOLIAR.

1. Venación secundaria de tipo broquidódroma

2. Venación secundaria de tipo broquidódroma promínula-reticulada

3. Areolas de $2-3 / \mathrm{mm}^{2}$

3. Cryptocarya aschersoniana

3'. Areolas de $6-8 / \mathrm{mm}^{2}$ 10. Ocotea aciphylla

2'. Venación secundaria de tipo broquidódroma no promínula-reticulada

4. Vénulas simples a ausentes; hojas con base cordada a subcordada

1. Aniba desertorum

4'. Vénulas ramificadas; hojas con base aguda, atenuada a obtusa

5. Nervaduras intersecundarias ausentes

17. Ocotea spixiana

5’. Nervaduras intersecundarias exmediales

6. Nervaduras terciarias mixtas alterna/opuesta-percurrentes

7. Domacios presentes en la axila de las nervaduras secundarias

7’. Domacios ausentes

8. Hojas glabrescentes, con tricomas en la yemas

14. Ocotea minarum

8'. Hojas glabras, sin tricomas en las yemas

6. Nectandra cissiflora

6’. Nervaduras terciarias alternas-percurrentes

9. Nervaduras secundarias con espaciamiento regular entre ellas

10. Hojas hirsutas

10'. Hojas glabrescentes

13. Ocotea diospyrifolia

9'. Nervaduras secundarias con espaciamiento creciente en dirección al ápice

11. Vénulas simples o ramificadas laxas

11’. Vénulas ramificadas dendríticas.

1'. Venación secundaria mixta eucamptódroma-broquidódroma

12. Hojas con márgenes acentuadamente revolutos

12’. Hojas con márgenes planos a levemente revolutos

13. Nervaduras intersecundarias ausentes

14. Nervaduras terciarias opuesta-percurrentes; número de pares de nervaduras secundarias de 3-5

12. Ocotea densiflora

14’. Nervaduras terciarias mixtas alterno/opuesta-percurrentes; número de pares de nervaduras secundarias 9-11

9. Nectandra warmingii

13’. Nervaduras intersecundarias exmediales presentes

15. Domacios presentes

8. Nectandra turbacensis

15'. Domacios ausentes

16. Areolas de $10-15 / \mathrm{mm}^{2}$; vénulas ausentes, raramente simples

16'. Areolas de 1-3/ $\mathrm{mm}^{2}$; vénulas ramificadas dendríticas

17. Hojas glabrescentes

7. Nectandra hihua

17'. Hojas tomentosas

18. Ocotea velloziana

15. Ocotea pomaderroides

DESCRIPCIÓN DEL PATRÓN DE VENACIÓN FOLIAR DE LAS ESPECIES

de Lauraceae del Distrito Federal

1. Aniba desertorum (Ness) Mez (Fig. 2:1-4)

Hojas ovadas, elípticas, oblongas a lanceoladas, 16-20 x 4-7,5 cm; relación foliar de 2,5-4, ápice redondeado a corto acuminado; base cordada a subcordada; lámina foliar coriácea; margen levemente revoluto; cara adaxial glabra; cara abaxial vilosa a glabrescente. Venación broquidódroma; nervaduras secundarias 9-11 pares simples o ramificadas, con espaciamiento irregular entre ellas, nervaduras intersecundarias exmediales; nervaduras terciarias alterno-percurrentes; areolas con 4-5 lados, 3-
4 por $\mathrm{mm}^{2}$, vénulas simples a ausentes. Pecíolo 0,2-1 cm, cilíndrico y glabrescente.

2. Aniba heringeri Vattimo-Gil (Fig. 2:5-8)

Hojas lanceoladas, elípticas a ovadas; de 10,5-16 x 3,3-6 cm; relación foliar de 2,6-3,1; ápice redondeadoapiculado a corto-acuminado; base aguda; lámina foliar coriácea; margen levemente revoluto; cara adaxial glabra a glabrescente; cara abaxial poco tomentosa a glabrescente. Venación broquidódroma; nervaduras secundarias de 7- 
10 pares, con espaciamiento que crecen en dirección a el ápice; nervaduras intersecundarias exmediales ramificadas interconectadas con las terciarias; nervaduras terciarias alterno-percurrentes; areola con 4-5 lados, 2-3 por $\mathrm{mm}^{2}$; vénulas simples a ramificadas laxas. Pecíolo 0,9-1,8 cm, canaliculado y glabrescente.

\section{Cryptocarya aschersoniana Mez (Fig. 2:9-12)}

Hojas elípticas a lanceoladas; de 10-17 x 3,6-5.5cm; relación foliar de 2,7-3; ápice agudo, acuminado a corto-acuminado; base atenuada a decurrente; lámina foliar cartácea a coriácea; margen plano; cara adaxial glabra; cara abaxial glabra. Venación broquidódroma promínulo-reticulada; nervaduras secundarias 8-11 pares, con espaciamiento irregular entre ellas; nervaduras intersecundarias exmediales; nervaduras terciarias alterno-percurrentes; areola con 4-5 lados, 2-3 por $\mathrm{mm}^{2}$; vénulas simples a ramificadas laxas. Pecíolo 1-2 cm, subcanaliculado y glabro.

4. Endlicheria paniculata (Spreng.) J.F.Macbr. (Fig. 3:13-16) Hojas elípticas a lanceoladas; de 10-15 x 4,2-8,2 cm; relación foliar de 1,8-2,3; ápice agudo a acuminado; base aguda, obtusa a cuneada; lámina foliar cartácea; margen levemente revoluto, cara adaxial y abaxial hirsutas, densamente hirsutas en las nervaduras. Venación broquidódroma; nervaduras secundarias 6-8 pares, con espaciamiento regular entre ellas; nervaduras intersecundarias exmediales; nervaduras terciarias alterna-percurrentes; aréolas con 4-5 lados, 1-2 $\mathrm{mm}^{2}$; vénulas ramificadas dendríticas. Pecíolo 0,7-1,8 cm, canaliculado y glabrescente.

5. Mezilaurus crassiramea (Meisn.) Taub. ex Mez (Fig. 3:17-20)

Hojas ovadas; de 10,4-15 x 4,8-9 cm; relación foliar de 1,6-2,6; ápice redondeado; base atenuada; lámina foliar coriácea; margen acentuadamente revoluto; caras adaxial y abaxial pilosas a glabrescentes, con concentración de pelos en las nervaduras en ambas caras. Venación eucamptódroma-broquidódroma; nervaduras secundarias 11-14 pares, con espaciamiento irregular entre ellas; nervaduras intersecundarias exmediales; nervaduras terciarias alterno-percurrentes; areolas con 4-5(6) lados, 3-4 $\mathrm{mm}^{2}$; vénulas ramificadas dendríticas. Pecíolo menor a $0,5 \mathrm{~cm}$, densamente piloso.

\section{Nectandra cissiflora Nees (Fig. 3:21-24)}

Hojas elípticas, largo-elípticas a ovadas; de 13-21 x 5,78,2 cm; relación foliar de 2,2-2,5; ápice acuminado a corto-acuminado; base atenuada a cuneada; lámina foliar cartácea a rígido-cartácea; margen plano y revoluto en la base; caras adaxial y abaxial glabras a glabrescentes. Venación broquidódroma, nervaduras secundarias 9-15 pares, con espaciamiento regular entre ellas; nervaduras intersecundarias exmediales; nervaduras terciarias mixtas alterna/opuesta-percurrentes; areolas con 4-5 lados, 3-4 por $\mathrm{mm}^{2}$; vénulas ramificadas dendríticas. Pecíolo 0,8-1,9, aplanado y con superficie denso-serícea.

\section{Nectandra hihua Ruiz \& Pav. (Fig. 4:25-28)}

Hojas elípticas a largo-elípticas; de 11-16,7 x 5,5-8 cm; relación foliar de 2-2,2; ápice acuminado; base redondeada a cuneada; lámina foliar cartácea; margen plano y resoluto en la base; cara adaxial glabra; cara abaxial glabrescente. Venación eucamptódroma-broquidódroma; nervaduras secundarias 8-10 pares, con espaciamiento entre ellas decrecientes en dirección hacia el ápice; nervaduras intersecundarias exmediales, nervaduras terciarias mixtas alterno/opuesta-percurrentes; areolas con 4-5 lados, 10-15 por $\mathrm{mm}^{2}$; vénulas ausentes, raramente simples. Pecíolo 0,7$1,5 \mathrm{~cm}$, cilíndrico y glabrescente.

8. Nectandra turbacensis (Kunth) Nees (Fig. 4:29-32) Hojas elípticas, lanceoladas, oblongas a ovadas; de 9,516,5 x 3,3-5 cm; relación foliar de 2,8-3,3; ápice agudo a obtuso; base aguda, atenuada a obtusa; lámina foliar cartácea; margen plano; caras adaxial y abaxial glabras. Venación eucampdódroma-broquidódroma; nervaduras secundarias 6-8 pares, con espaciamiento regular entre ellas, domacios faveolados en la región axilar; nervaduras intersecundarias exmediales; nervaduras terciarias alterna/ opuesta-percurrentes; areolas con (3)4-5 lados, 2-3 por $\mathrm{mm}^{2}$; vénulas ramificadas dendríticas. Pecíolo $0,5-1 \mathrm{~cm}$, canaliculado y glabro.

9. Nectandra warmingii Meisn. (Fig. 4:33-36)

Hojas elípticas a lanceoladas, de 10-15 x 4-5 cm; relación foliar de 2,5-3; ápice agudo; base atenuada y revoluta; cara adaxial glabra en la lámina y nervadura primaria glabrescente; lámina foliar cartácea; margen levemente revoluto; cara abaxial glabrescente, con tricomas más largos en la región axilar de las nervaduras secundarias. Venación eucamptódromo-broquidódroma; nervaduras secundarias 911 pares, con espaciamiento regular entre ellas; nervaduras intersecundarias ausentes; nervaduras terciarias mixtas alterna/opuesta-percurrentes; areolas con 4-5 lados; 3-4 por $\mathrm{mm}^{2}$; vénulas simples a ramificadas laxas. Pecíolo 0,5-1.4 cm, cilíndrico y glabrescente.

10. Ocotea aciphylla (Nees) Mez (Fig. 5:37-40)

Hojas elípticas a oblongas; de 9-13 x 3,2-4.3 cm; relación foliar de 2,8-3; ápice acuminado a largo acuminado; base obtusa; lámina foliar cartácea; margen levemente revoluto; cara adaxial glabra en la lámina y nervadura primaria; cara abaxial glabrescente. Venación broquidódroma promínula-reticulada; nervaduras secundarias 7-9 pares, con espaciamiento entre ellas creciendo en dirección a el ápice; nervaduras intersecundarias exmediales; nervaduras terciarias alterna-percurrentes; areolas con (3)4-5 lados, 6-8 
por $\mathrm{mm}^{2}$; vénulas ausentes y simples. Pecíolo 0,5-1,15 cm, canaliculado y glabrescente.

11. Ocotea corymbosa Mez (Fig. 5:41-44)

Hojas elípticas; de 8-13,5 x 2,5-4,8 cm; relación foliar de 2,83,2; ápice corto a largo-acuminado; base atenuada a aguda; lámina foliar cartácea a coriácea; margen plano a levemente revoluto; cara adaxial glabra; cara abaxial glabraaglabrescente. Venación broquidódroma; nervaduras secundarias 8-11 pares, con espaciamiento entre ellas creciendo en dirección hacia el ápice; nervaduras intersecundarias exmediales; nervaduras terciarias alterna-percurrentes; areolas con 4-5 lados, 2-3 por $\mathrm{mm}^{2}$; vénulas ramificadas dendríticas. Pecíolo 0,5-1,4 cm, canaliculado y glabrescente.

\section{Ocotea densiflora (Meisn.) Mez (Fig. 5:45-48)}

Hojas elípticas, largo-elípticas a oblongas; de 8-12 x 2,5$4 \mathrm{~cm}$; relación foliar de 3-3,2; ápice corto-acuminado a acuminado; base aguda, obtusa, atenuada a levemente asimétrica; lámina foliar cartácea a coriácea; margen plano a levemente revoluto; cara adaxial glabra a glabrescente; cara abaxial lanosa, con tricomas de color castaño. Venación eucamptódroma-broquidódroma; nervaduras secundarias 34 pares, con espaciamiento regular entre ellas; nervaduras intersecundarias ausentes; nervaduras terciarias opuestapercurrentes; areolas con 4-5 lados, 2-3 por $\mathrm{mm}^{2}$; vénulas ramificadas laxas y dendríticas. Pecíolo 0,5-1,5 cm, subcanaliculado y glabrescente.

13. Ocotea diospyrifolia (Meisn.) Mez (Fig. 6:49-52) Hojas elípticas a lanceoladas; de 7-12 x 3-5cm; relación foliar de 2,3-2,5; ápice corto-acuminado; base aguda a atenuada; lámina foliar cartácea; margen levemente revoluto; caras adaxial y abaxial glabras. Venación broquidódroma; nervaduras secundarias 9-12 pares, con espaciamiento regular entre ellas; nervaduras intersecundarias exmediales; nervaduras terciarias alterno-percurrentes; areolas con (3)4-5 lados, 2-3 por $\mathrm{mm}^{2}$; vénulas ramificadas dendríticas. Pecíolo 0,7-1 cm, canaliculado y glabro.

\section{Ocotea minarum (Nees) Mez (Fig. 6:53-56)}

Hojas elípticas a estrecho-elípticas; de 9-15 x 2,5-4 cm; relación foliar de 3,6-3,8; ápice corto-acuminado a obtuso; base decurrente; lámina foliar cartácea; margen levemente revoluto; caras adaxial y abaxial glabrescentes. Venación broquidódroma; nervaduras secundarias 11-15 pares, con espaciamiento decreciente en dirección hacia el ápice, con domacios en la región axilar; nervaduras intersecundarias exmediales; nervaduras terciarias mixtas alterna/opuestapercurrentes; areolas con (3)4-5 lados, 1-2 por mm²; vénulas ramificadas dendríticas. Pecíolo 0,5-1,4 cm, canaliculado y glabrescente.
15. Ocotea pomaderroides (Meisn.) Mez (Fig. 6:57-60)

Hojas elípticas; de 7-11 x 2,5-3 cm; relación foliar de 2,8-3,6; ápice corto acuminado; base aguda; lámina foliar coriácea; margen levemente revoluto; cara adaxial glabra; cara abaxial tomentosa. Venación eucamptódromabroquidódroma; nervaduras secundarias 9-12 pares, con espaciamiento decreciente en dirección hacia el ápice, nervaduras intersecundarias exmediales; nervaduras terciarias alterna-percurrentes; areolas con 4-5 lados, 2-3 $\mathrm{mm}^{2}$; vénulas ramificadas dendríticas. Pecíolo 0,6-1,7 cm, canaliculado y tomentoso.

16. Ocotea pulchella Mart.(Fig. 7:61-64)

Hojas ovadas, lanceoladas a elípticas; de 7,2-11 x 2,5-3,4 cm; relación foliar de 2,8-3,2; ápice acuminado a obtuso; base aguda a atenuada; lámina coriácea; margen plano a levemente revoluto; caras adaxial y abaxial glabrescentes en la lámina y densamente piloso en la nervadura primaria. Venación broquidódroma; nervaduras secundarias 6-8 pares, con espaciamiento regular entre ellas; nervaduras intersecundarias exmediales; nervaduras terciarias alternapercurrentes; areolas con 4-5 lados, 1-3 por $\mathrm{mm}^{2}$; vénulas ramificadas dendríticas. Pecíolo 0,4-1 cm, canaliculado y tomentoso.

17. Ocotea spixiana (Nees) Mez (Fig. 7:65-68)

Hojas ovadas, elípticas a lanceoladas; de 9-12 x 4-5 cm; relación foliar de 2,2-2,5; ápice agudo a corto-acuminado; base aguda; lámina foliar coriácea; margen levemente revoluto; cara adaxial glabrescente a tomentosa; cara abaxial tomentosa. Venación broquidódroma; nervaduras secundarias 7-8 pares, con espaciamiento regular entre ellas, con domacios en las regiones axilares; nervaduras intersecundarias ausentes; nervaduras terciarias mixtas alterna/opuesta-percurrentes; areolas con 4-5 lados, 3,4 por $\mathrm{mm}^{2}$; vénulas ramificadas dendríticas. Pecíolo $1-2 \mathrm{~cm}$, canaliculado y densamente tomentoso.

18. Ocotea velloziana (Meisn.) Mez (Fig. 7:69-72)

Hojas lanceoladas a largo-elípticas; de 6,5-8 x 4,5-6,2 cm; relación foliar de 1,2-1,4; ápice generalmente cortoacuminado; base cuneada; lámina foliar coriácea; margen levemente revoluto; cara adaxial glabra en la lámina y nervadura primaria glabrescente; cara abaxial glabrescente. Venación eucamptódroma-broquidódroma; nervaduras secundarias 7-11 pares, con espaciamiento regular entre ellas; nervaduras intersecundarias exmediales; nervaduras terciarias mixtas alterna/opuesta-percurrentes; areola con (3)4-5 lados, 1-2 por $\mathrm{mm}^{2}$, vénulas ramificadas dendríticas. Pecíolo 0,7-1,8 cm, canaliculado y glabrescente. 


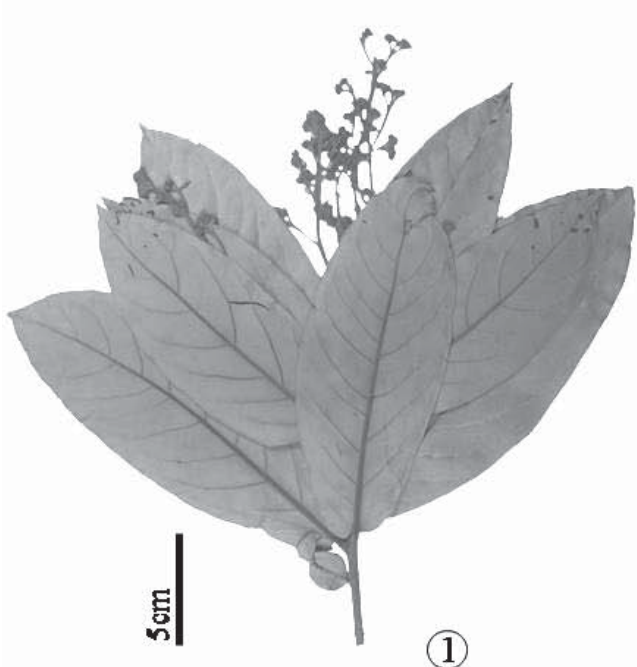

(1)
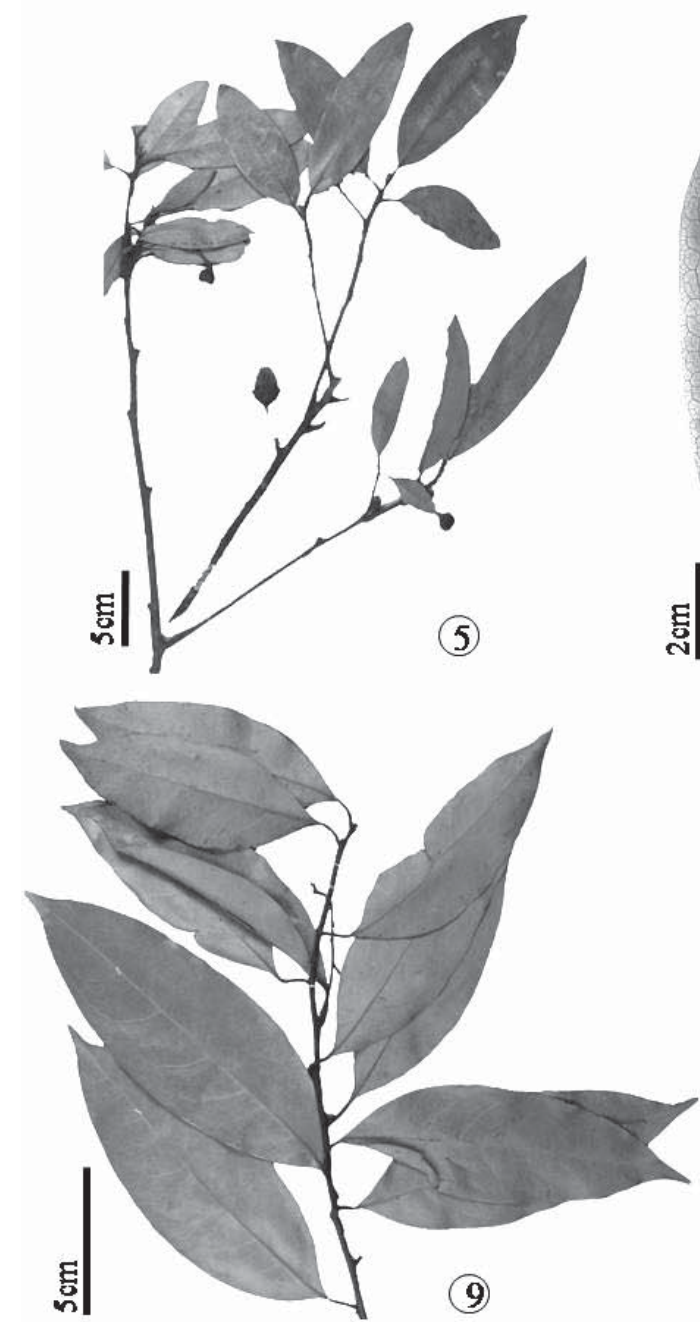
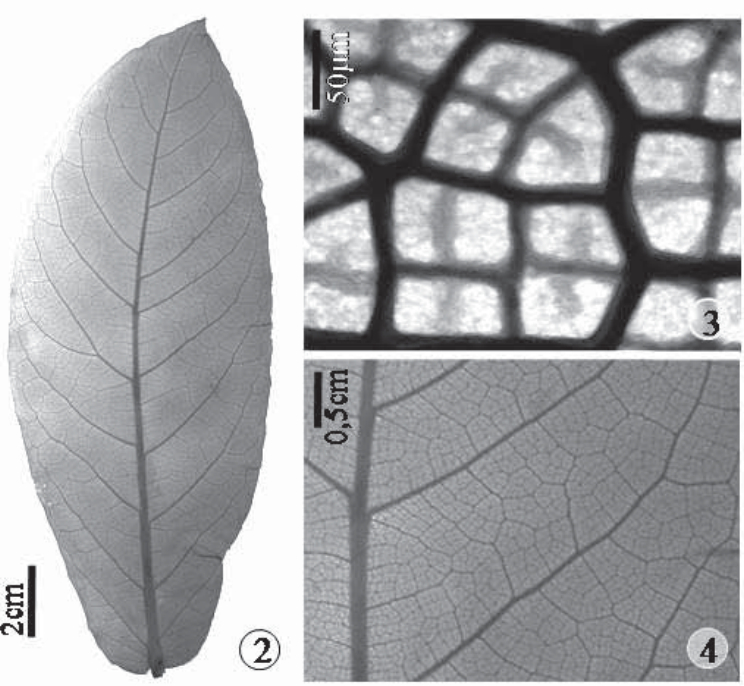

(2)
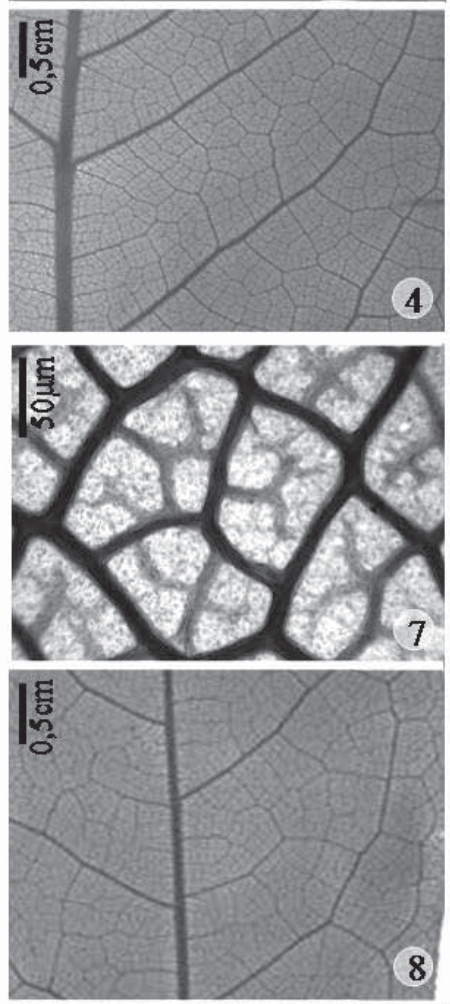

(6)
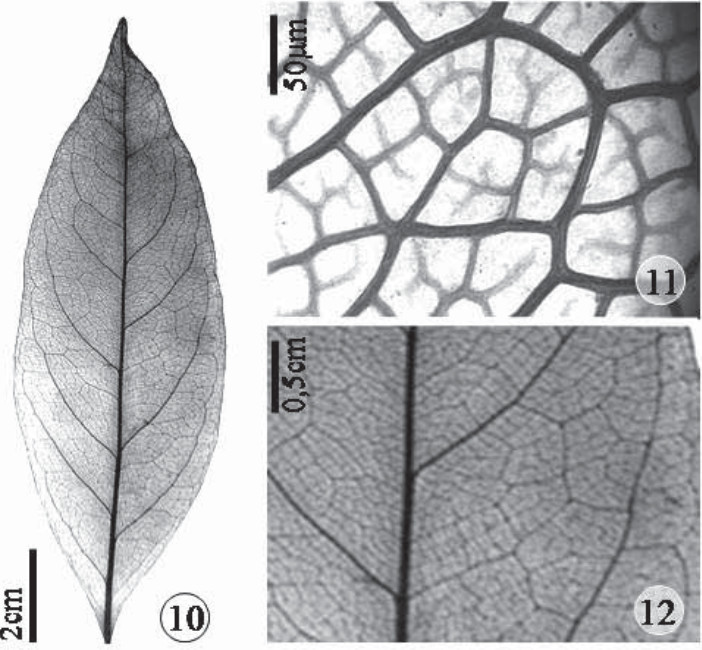

Figura 2. 1-4. Aniba desertorum. 5-8. A. heringeri. 9-12. Cryptocarya aschersoniana. 1, 5, 9. Tallo, aspecto general. 2, 6, 10. Hoja diafanizada. 3, 7, 11. Detalle de las areolas con las terminaciones de vénulas. 4, 8, 12. Detalle de las nervaduras secundarias.

Figure 2. 1-4. Aniba desertorum. 5-8. A. heringeri. 9-12. Cryptocarya aschersoniana. 1, 5, 9. Branch, general aspect. 2, 6, 10. Claryfied leaf. 3, 7, 11. Detail of the areole with veinlets terminations. 4, 8, 12. Details of the secondary venation. 

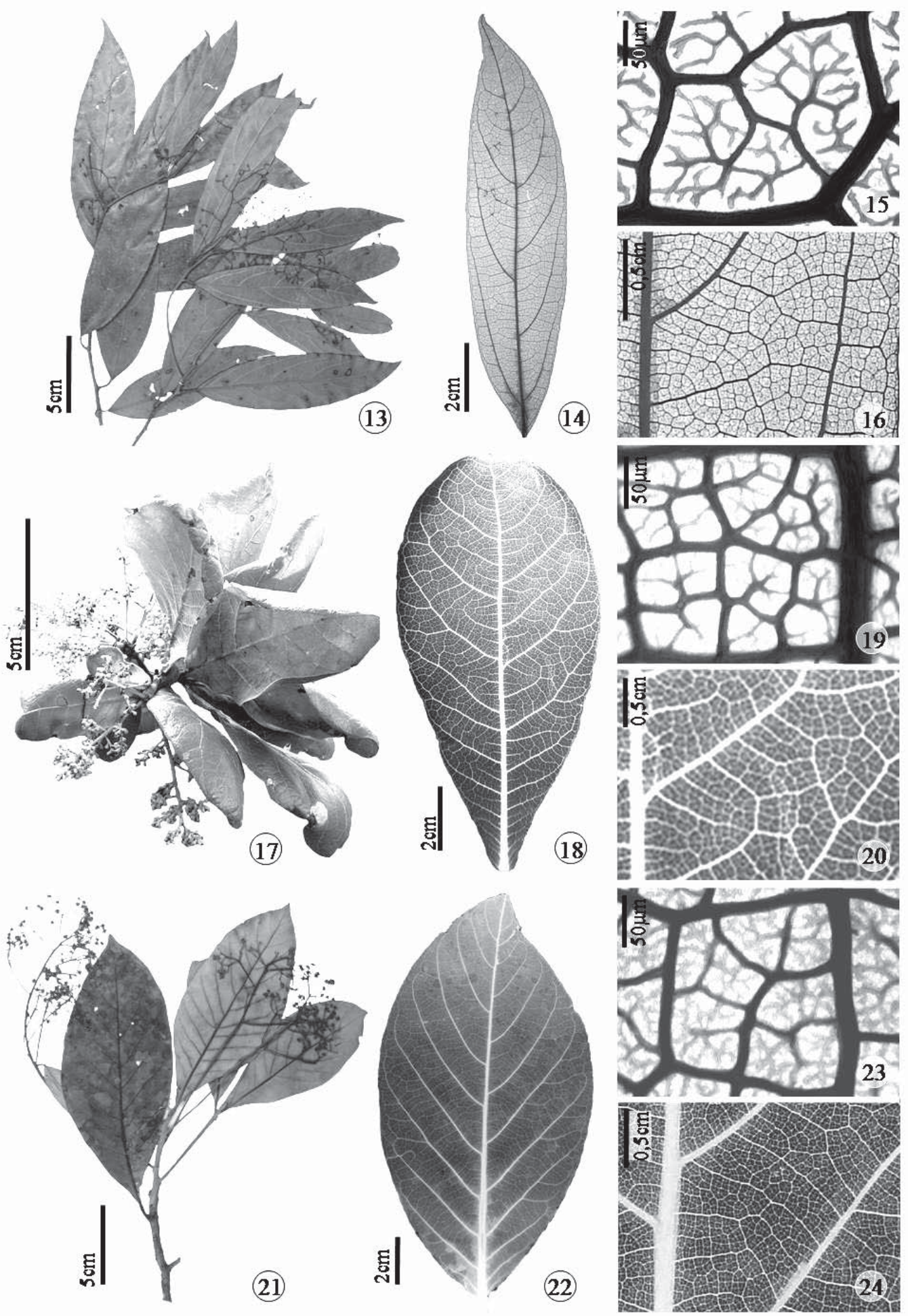

Figura 3. 13-16. Endlicheria paniculata. 17-20. Mezilaurus crassiramea. 21-24. Nectandra cissiflora. 13, 17, 21. Tallo, aspecto general. 14, 18, 22. Hoja diafanizada. 15, 19, 23. Detalle de las areolas con las terminaciones de vénulas. 16, 20, 24. Detalle de las nervaduras secundarias.

Figure 3. 13-16. Endlicheria paniculata. 17-20. Mezilaurus crassiramea. 21-24. Nectandra cissiflora. 13, 17, 21. Branch, general aspect. 14, 18, 22. Claryfied leaf. 15, 19, 23. Detail of the areole with veinlets terminations. 16, 20, 24. Details of the secondary venation. 

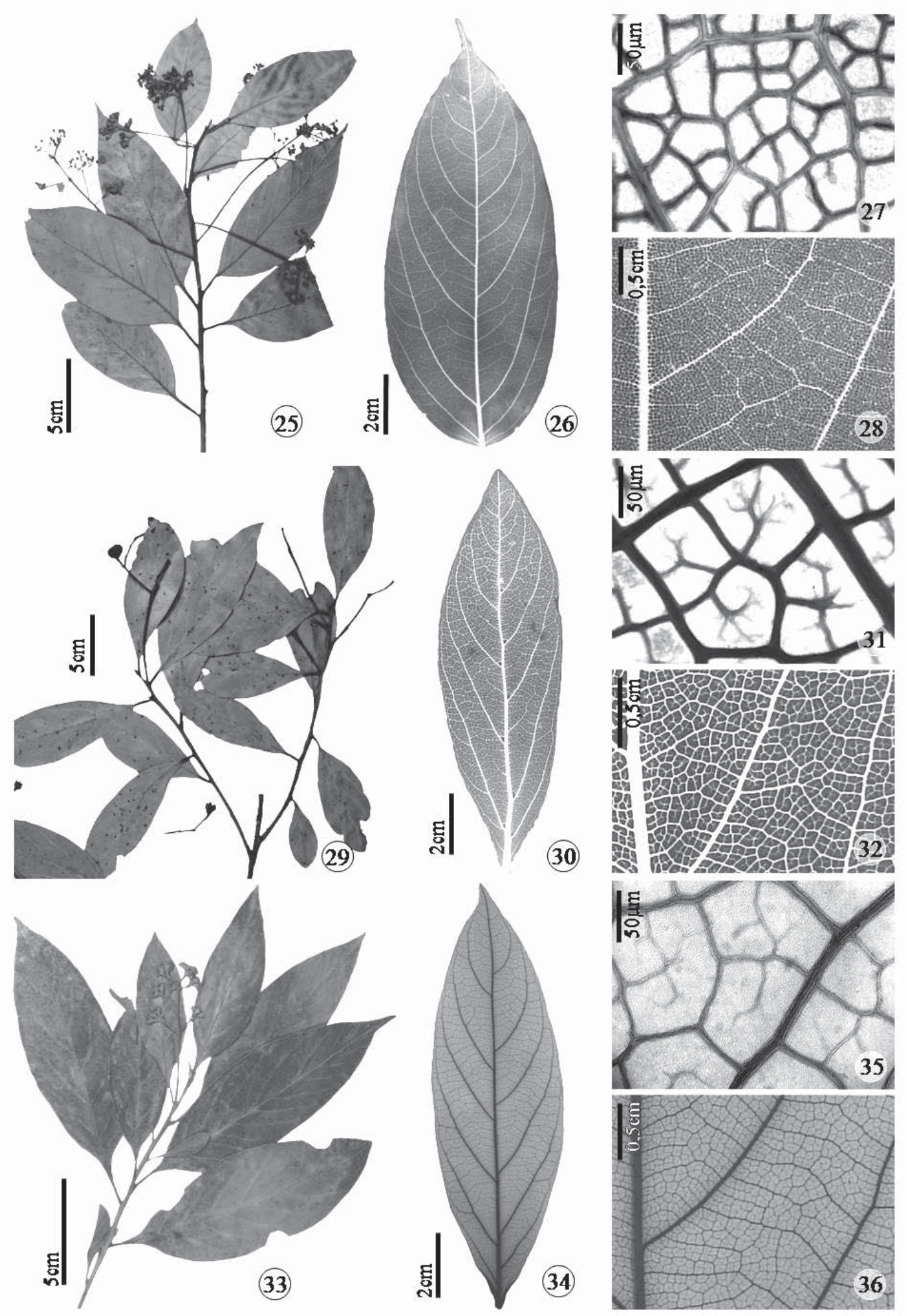

Figura 4. 25-28. Nectandra hihua. 29-32. N. turbacensis. 33-36. N. warmingii. 25, 29, 33. Tallo, aspecto general. 26, 30, 34. Hoja diafanizada. 27, 31, 35. Detalle de las areolas con las terminaciones de vénulas. 28, 32, 36. Detalle de las nervaduras secundarias.

Figure 4. 25-28. Nectandra hihua. 29-32. N. turbacensis. 33-36. N. warmingii. 25, 29, 33. Branch, general aspect. 26, 30, 34. Claryfied leaf. 27, 31, 35. Detail of the areole with veinlets terminations. 28, 32, 36. Details of the secondary venation. 

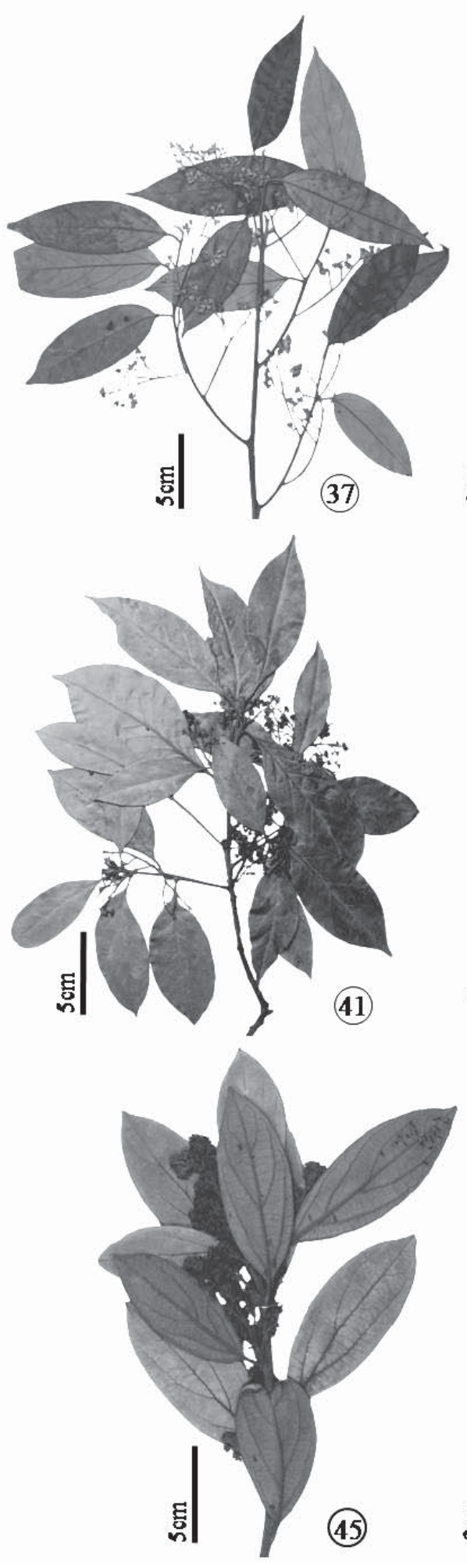
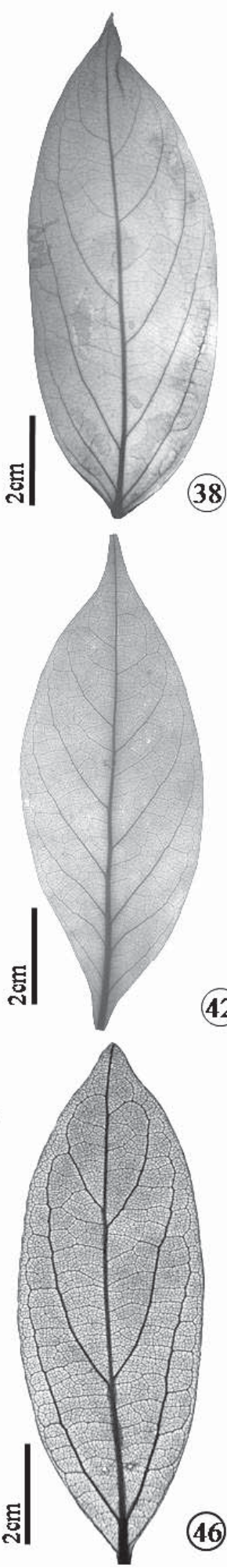
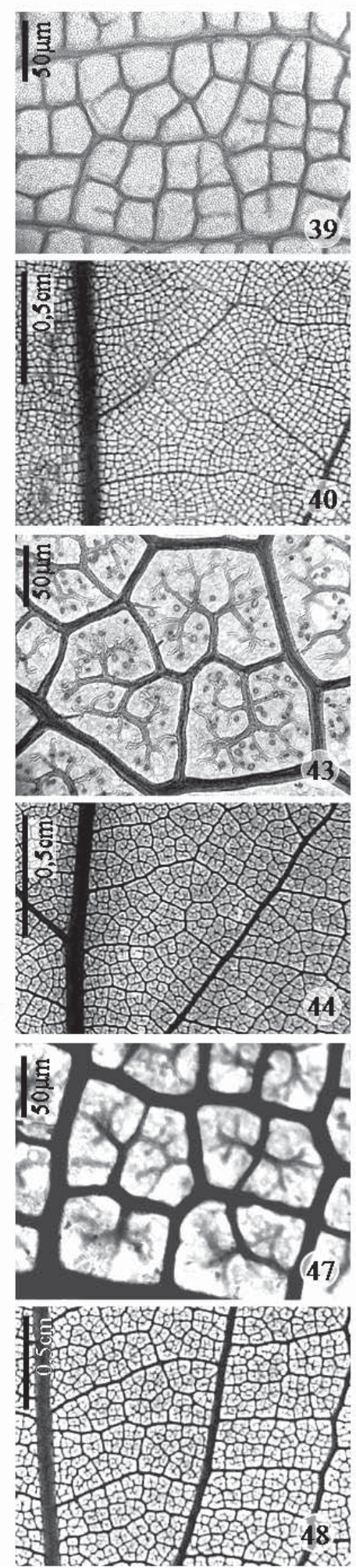

Figura 5. 37-40. Ocotea aciphylla. 41-44. O. corymbosa. 45-48. O. densiflora. 37, 41, 45. Tallo, aspecto general. 38, 42, 46. Hoja diafanizada. 39, 43, 47. Detalle de las areolas con las terminaciones de vénulas. 40, 44, 48. Detalle de las nervaduras secundarias.

Figure 5. 37-40. Ocotea aciphylla. 41-44. O. corymbosa. 45-48. O. densiflora. 37, 41, 45. Branch, general aspect. 38, 42, 46. Claryfied leaf. 39, 43, 47. Detail of the areole with veinlets terminations. 40, 44, 48. Details of the secondary venation. 

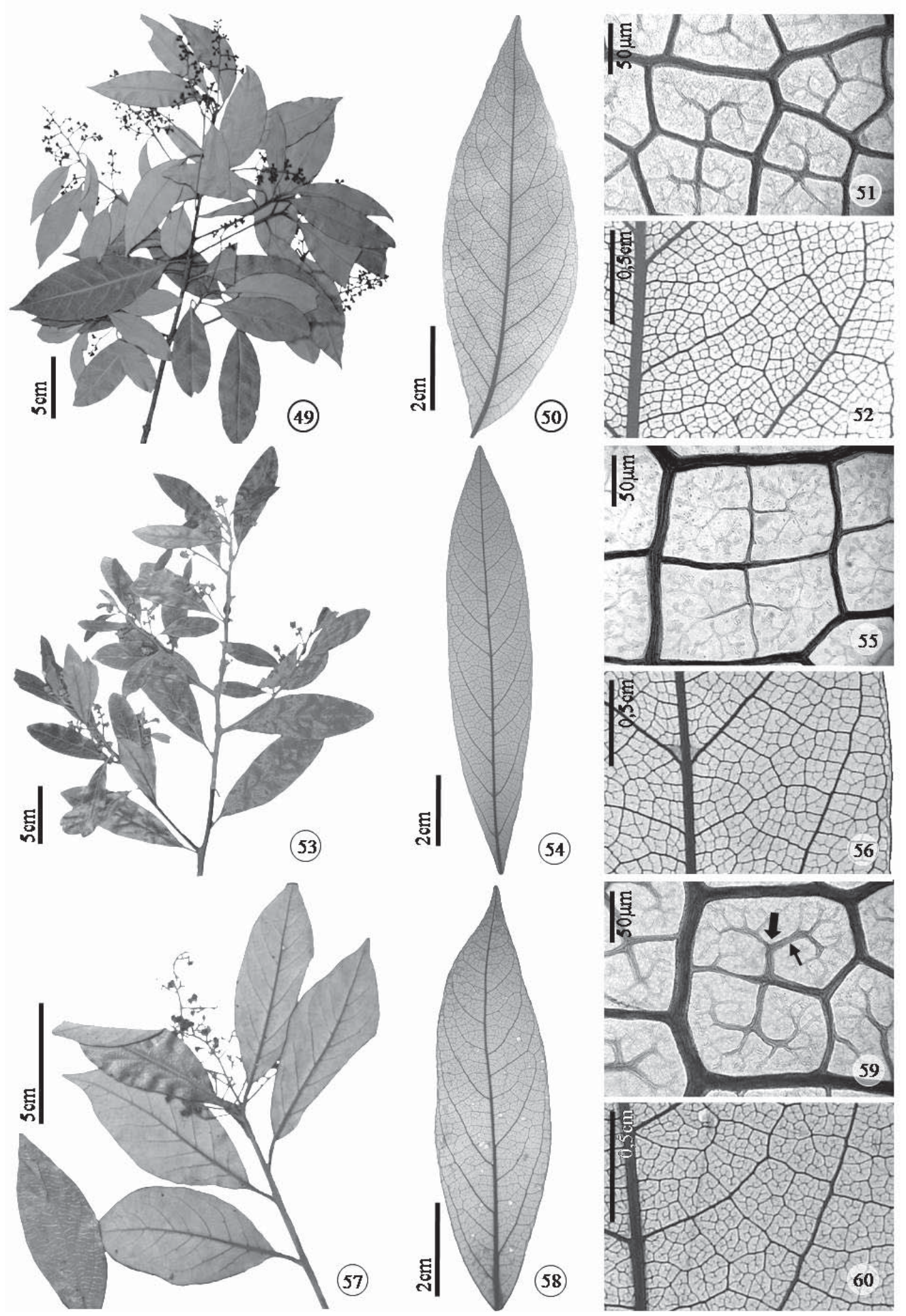

FiguRa 6. 49-52. Ocotea diospyrifolia. 53-56. O. minarum. 57-60. O. pomaderroides. 49, 53, 57. Tallo, aspecto general. 50, 54, 58. Hoja diafanizada. 51, 55, 59. Detalle de las areolas con las terminaciones de vénulas. 52, 56, 60. Detalle de las nervaduras secundarias. Leyenda: flecha grande: nudo; flecha estrecha: rama de la vénula.

Figure 6. 49-52. Ocotea diospyrifolia. 53-56. O. minarum 57-60. O. pomaderroides. 49, 53, 57. Branch, general aspect. 50, 54, 58. Claryfied leaf. 51, 55, 59. Detail of the areole with veinlets terminations. 52, 56, 60. Details of the secondary venation. Subtitle: big arrow - knot; small arrow - ramification of the vein. 

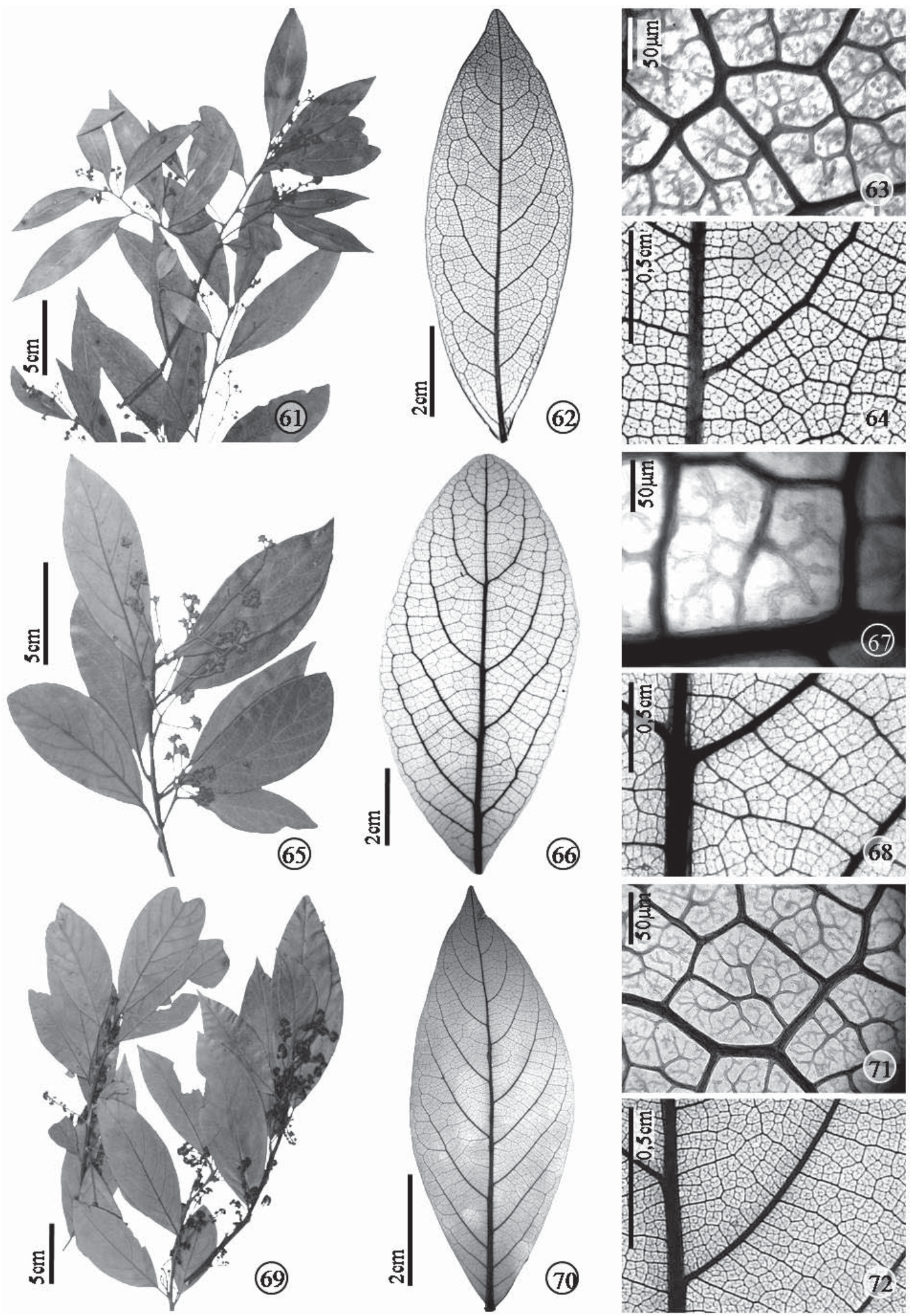

Figura 7. 61-64. Ocotea pulchella. 65-68. O. spixiana. 69-72. O. velloziana. 61, 65, 69. Tallo, aspecto general. 62, 66, 70. Hoja diafanizada. 63, 67, 71. Detalle de las areolas con las terminaciones de vénulas. 64, 68, 72 Detalle de las nervaduras secundarias.

Figure 7. 61-64. Ocotea pulchella. 65-68. O. spixiana. 69-72. O. velloziana. 61, 65, 69. Branch, general aspect. 62, 66, 70. Claryfied leaf. 63, 67, 71. Detail of the areole with veinlets terminations. 64, 68, 72. Details of the secondary venation. 


\section{DISCUSIÓN}

El patrón broquidódromo encontrado en las especies analizadas coincide con los resultados obtenidos en otros estudios de la familia (Hickey 1974, Coe-Teixeira 1980, Van der Werff 1993, Moraes \& Paoli 1999, Moraes \& Oliveira 2007).

El ángulo de la divergencia de las nervaduras secundarias en relación a la nervadura primaria no fue considerado como un buen carácter taxonómico para la distinción de las especies analizadas, ya que todas ellas variaron entre los 60$75^{\circ}$, inclusive entre hojas del mismo individuo.

El número de pares de nervaduras secundarias mostró un importante carácter en la separación de Ocotea densiflora (3-4 pares) y distinguió esta especie de las demás.

Los espaciamientos entre las nervaduras secundarias fueron un importante carácter para la separación de mitad de las especies; espaciamientos irregulares en Aniba desertorum, Cryptocarya aschersoniana y Mezilaurus crassiramea; espaciamientos crecientes en dirección al ápice foliar en A. heringeri, Ocotea aciphylla y $O$. corymbosa; y espaciamiento decreciente en dirección al ápice en Nectandra hihua, Ocotea minarum y $O$. pomaderroides. Las nervaduras intersecundarias exmediales fueron comunes entre las especies estudiadas, pero la ausencia de éstas puede ser considerada como carácter importante en la taxonomía de la familia, puesto que tres de las especies analizadas no presentaron esta característica (N. warmingii, Fig. 4:36; O. densiflora, Fig. 5:48 y O. spixiana, Fig.7:66).

Las nervaduras terciarias en la mayoría de las especies fueron alterna-percurrentes, siendo sólo en Ocotea densiflora (Fig. 5:48) de tipo opuesta-percurrente. El patrón mixto alterna/opuesta-percurrente fue observado en $N$. cissiflora, $N$. hihua, N. warmingii, O. minarum, O. spixiana y $O$. velloziana.

Las nervaduras del cuarto y quinto orden fueron las que definieron las areolas poligonales bien desarrolladas para todas las especies, como ya lo indicó Coe-Teixeira (1980) en un estudio similar para el género Ocotea del estado de São Paulo (Brasil).

El número de lados de las areolas no fue un carácter muy útil en la distinción taxonómica, pues se mostró constante entre todas las especies estudiadas (4-5 lados). Sin embargo la densidad de areolas por $\mathrm{mm}^{2}$ indico una diferencia entre ellas: $N$. hihua fue la especie que se presentó con la densidad más alta de todas (10-15). Esta igualdad en densidad de areolas está presente en géneros como Spathicarpa (Araceae) como lo describe Fonsêca et al. (2007), por tanto este carácter puede a veces tener una relevancia taxonómica en determinado taxones y no en otros.

La mayoría de las especies estudiadas presentan vénulas ramificadas. Vénulas simples o la ausencia de éstas fueron observadas solamente en A. desertorum (Fig. 2:3), $N$. hihua (Fig. 4:27) y O. aciphylla (Fig. 5:39), coincidiendo con esta última especie los resultados obtenidos por Coe-Teixeira (1980).

El tipo de ramificación de las vénulas posibilitó el agrupamiento de las especies estudiadas. Vénulas ramificadas aparecen en 15 especies, quedando $A$. heringeri (Fig. 2:7), C. aschersoniana (Fig. 2:11) y N. warmingii (Fig. 4:35) como las únicas especies que poseen vénulas ramificadas laxas, por tanto los caracteres expresados por las vénulas fueron de mucha ayuda en la separación de las especies estudiadas.

Hojas de $N$. turbacensis, O. minarum y O. spixiana presentan domacios en la región axilar de las nervaduras secundarias. Stace (1965) indicó que es común la ocurrencia de estas estructuras en esta región y resalta su importancia taxonómica. Especies de Ocotea, Cinnamomun y Nectandra pueden presentar domacios o no, constituyendo un carácter que viene siendo usado en la distinción de las especies de la familia (Coe-Teixeira 1980; Quinet 2006).

El presente trabajo analizó los caracteres generales considerados en trabajos de arquitectura foliar y propuso la utilización de caracteres adicionales, como espaciamiento entre las nervaduras secundarias, ángulo de divergencia de éstas en relación a la primaria, densidad de areolas (cantidad por $\mathrm{mm}^{2}$ ), número de lados y la clasificación de la vénulas. De estos caracteres mencionados sólo el ángulo de divergencia y el número de lados de las areolas no fueron eficientes en la separación de las especies estudiadas.

Los caracteres analizados no son eficaces para la separación de los géneros estudiados, pero proporcionaron la distinción de las especies, posibilitando así la elaboración de claves taxonómicas de identificación. Resultados semejantes fueron obtenidos con otros taxones como el realizado por Alvarez et al. (2006) en Eugenia, y Fonsêca et al. (2007) estudiando el género Spathicarpa Hook. (Araceae), por lo cual el presente estudio demuestra su gran utilidad en la taxonomía de Lauraceae.

En cuanto a las técnicas utilizadas para la diafanización de las hojas, se tuvo la necesidad de ajustar las concentraciones y tiempo utilizados normalmente. Se observó que las concentraciones de $20 \%$ de hidróxido de sodio e hipoclorito de sodio fueron las más adecuada para las especies aquí estudiadas. Concentraciones superiores provocaron la destrucción de la epidermis y los tejidos.

El barniz vitral incoloro de la GP Arts ${ }^{\circledR}$ usado en el proceso de montaje de las láminas de las especies analizadas mostró una buena transparencia, aparte de ser también más práctico en el manejo y por tener un tiempo menor en el secado en relación al de la marca Acrilex ${ }^{\circledR}$ utilizado por Paiva et al. (2006). 


\section{AGRADECIMIENTOS}

A la Coordenação de Aperfeiçoamento de Pessoal de Nível Superior - CAPES, por los fondos proporcionados para la realización de maestría concedida a la primera autora de este trabajo. A los curadores de los herbarios HEPH, IBGE y UB, por su predisposición en la dotación del material vegetal. Al Profesor Luiz Antonio Souza por la lectura y sugerencias del manuscrito.

\section{BIBLIOGRAFÍA}

ADOBE Systems Incorporated. 2002. Photoshop 7.0.1. Todos os direitos reservados.

Alvarez, A.S., R.C.V. Potiguara \& J.U.M. Santos. 2006. Arquitetura foliar de espécies de Eugenia L. (Myrtaceae) da restinga de Algodoal, Maiandeua, Pará. Boletim do Museu Paraense Emílio Goeldi. Ciências Naturais 1(2): 29-36.

BIU, C.C. 2008. Arquitetura foliar comparativa de Miconia sellowiana (DC.) Naudin (Melastomataceae) em diferentes fitofisionomias. Dissertação de Mestrado, Universidade Federal do Paraná, Brasil. 49 pp.

Cheng-Hong, Y. \& C. Ze-Lian. 1991. Leaf architecture of the woody dicotyledons from tropical and subtropical China. Ed. IAP, Guangzhou, China. 305 pp.

Christophel, D.C., R. Kerrigan \& A.I. Rowett. 1996. The use of cuticular features in the taxonomy of the Lauraceae. Annals of the Missouri Botanical Garden 83: 419-432.

Coe-Teixeira, B. 1980. Lauráceas do gênero Ocotea, do estado de São Paulo. Rodriguésia 52: 55-190.

FERnANDES, S.D.C. 2007. Morfologia, anatomia, histoquímica e aspectos fisiológicos da lâmina foliar de espécies de Clusia (Clusiaceae). Dissertação de Mestrado. Universidade de Brasília, Brasil. 134 pp.

Fonsêca, L.C.M., C.E.B. Proença \& E. Gonçalves. G. 2007. Descrição do padrão de venação foliar em Spathicarpa Hook. (Araceae). Acta Botanica Brasilica 21(1): 213-221.

Hickey, L.J. 1974. Clasificación de la arquitectura de las hojas de dicotiledóneas. Boletín de la Sociedad Argentina de Botánica 16(1/2): 1-26.

Holmgren, P.K., N.H. Holmgren \& L.C. Barnett. 1990. Index Herbariorum. Part. 1: The herbaria of the world, Regnum Vegetabile. New York Botanical Garden, New York. 520 pp.

Judd, W.S., C.S. Campbell, E.A. Kellog \& P.F. Stevens. 1999. Plant Systematics - a phylogenetic approach. Sinauer Associetes, Sunderland, Massachusetts. 464 pp.

KLUCKING, E.P. 1987. Leaf venation patterns. v. 2. (Lauraceae). J. Cramer, Berlin. 730 pp.

Kostermans, A.J.G.H. 1957. Lauraceae. Reinwardtia 4(2): 193256.

LAWG, LeAf Architecture Working Group. 1999. Manual of leaf Architecture-morphological description and categorization of dicotiledonous and net-veined monocotyledonous angiosperms. Department of Paleobiology, Smithsonian Institution, Washington. $67 \mathrm{pp}$.

Macedo, E.G., B.G. Santos-Filho \& R.C.V. Potiguara. 2005.
Anatomia e arquitetura foliar de Montrichardia linifera (Arruda) Schott (Araceae) espécie da várzea Amazônica. Boletim do Museu Paraense Emílio Goeldi (Ciências Naturais) 1(1): 19-43.

Moraes, P.L.R. \& A.A.S. Paoli. 1999. Epiderme e padrão de venação foliar de Lauraceae. Acta Botanica Brasilica 13(1): 87-97.

Moraes, P.L.R. \& J.M.B. Oliveira. 2007. Lauraceae Juss. Flora dos estados de Goiás e Tocantins (Coleção Rizzo v. 33). PRPPG/UFG, Goiânia. 154 pp.

Mendonça, R.C., J.M. Felfili, B.M.T. Walter, M.C. Silva Junior, A.V. Rezende, T.S. Filgueiras, P.E. Nogueira \& C.W. FAGG. 2008. Flora vascular do Bioma Cerrado. In: S.M. Sano, S.P. Almeida \& J.F. Ribeiro (eds.), Cerrado: Ecologia e Flora. V.2. Brasília: EMBRAPA, p. 422-1279.

Paiva, J.G.A., S.M.F. Carvalho, M.P. Magalhães \& D.G. Graciano-RibeIRo. 2006. Verniz vitral incolor 500: uma alternativa de meio de montagem economicamente viável. Acta Botanica Brasilica 20(2): 257-264.

Proença, C.E.B., C.B.R. Munhoz, C.L. Jorge \& M.G.G. NóBregA. 2001. Listagem e nível de proteção das espécies de fanerógamas do Distrito Federal, Brasil. In: T.B. Cavalcanti, \& A.E. Ramos (org.). Flora do Distrito Federal v. 1. EMBRAPA/CPAC, Brasília. 359 pp.

Quinet, A. 2005. Sinopse taxonômica da família Lauraceae no estado do Rio de Janeiro, Brasil. Acta Botanica Brasilica 19(3): 563-572.

Quinet, A. 2006. Lauraceae na Reserva Biológica de Poço das Antas, Silva Jardim, Rio de Janeiro, Brasil. Rodriguésia 57(3): 543-568.

RAJ, B. \& H. VAN DER. WerfF. 1988. A contribution to the pollen morphology of neotropical Lauraceae. Annals of the Missouri Botanical Garden 75(1): 130-167.

Reis, C., S.L. Proença \& M.G. Sajo. 2004. Vascularização foliar e anatomia do pecíolo de Melastomataceae do cerrado do Estado de São Paulo, Brasil. Acta Botanica Brasilica 18(4): 987-999.

Shobe, W.R. \& N.R. Lersten. 1967. A technique for clearing and staining gymnosperm leaves. Botanical Gazette 127(2): 150-152.

Silva Júnior, M.C., J.M. Felfili, B.M.T. Walter, P.E. Nogueira, A.V. Rezende, R.O. Morais \& M.G.G. Nóbrega. 2001. Análise da flora arbórea de Matas de Galeria no Distrito Federal: 21 levantamentos. In: J.F. Ribeiro, C.E.L. Fonseca \& J.C. Souza-Silva (eds). Cerrado-caracterização e recuperação de Matas de Galeria. EMBRAPA, Planaltina, DF. 899 pp.

SouzA, H.M. \& H.Lorenzi. 2005. Botânica Sistemática: Guia ilustrado para identificação das famílias de Angiospermas da flora brasileira, baseado em APG II. Instituto Plantarum, Nova Odessa. 610 pp.

StaCe, C.A. 1965. Cuticular studies as an aid to plant taxonomy. Bulletin of the British Museum (Natural History) 4: 3-78.

Vicentini, A., H. Van Der WerfF, \& S.Nicolau. 1999. Lauraceae. In: Flora da Reserva Ducke - Guia de identificação das plantas vasculares de uma floresta de terra firme na Amazônia Central, edited by J.E.L. da S. Ribeiro, M.J.G. Hopkins, A. Vicentini, C.A. Sothers, M.A.S. Costa, J.M. Brito, M.A.D. Souza, L.H.P. Martins, L.G. Lohmann, P.A.C.L. Assunção, E.C. Pereira, C.F. Silva, M.R. Mesquita \& L.C. Procópio, v. 1: 150-179. INPA/DFID, Manaus. 790 pp. 
WerfF, H. VAn Der. 1993. A revision of the genus Pleurothyrium (Lauraceae). Annals of the Missouri Botanical Garden 80: 39-118.

Anexo 1: Los términos utilizados en las descripciones.

AnNex 1: Terms used in the descriptions.

Relación foliar: el valor obtenido dividiendo la longitud de la hoja por su ancho, donde se expresan los valores mínimo y máximo obtenidos.

Ángulo de divergencia: ángulo medido a partir de la divergencia de las venas secundarias con respecto a la vena primaria en la línea media de la lámina foliar, utilizando un transportador y una lupa cartográfica.

Nervadura primaria: hemos utilizado las denominaciones: impresa (depresión leve), surcada (formando pequeña ranura), canaliculada (surco profundo, que forma un canal), plana (cerca de la misma altura de la lámina) y prominente (saliente).

Nervaduras secundarias: las que vienen de la vena principal, tienen diámetro más pequeño que ésta y definen el patrón de venación de las hojas de una especie.

Patrón broquidódromo: es aquello en lo que las venas secundarias están conectadas formando una serie de arcos prominentes.

Patrón eucamptódromo: cuando las venas secundarias se orientan hacia el ápice con una disminución gradual en el tamaño, sin tocar la margen, y se conectan con otras secundarias a través de una serie de venas terciarias, sin formar arcos marginales con las otras secundarias.

Nervaduras intersecundarias: se definen como las de tamaño intermedio entre las terciarias y secundarias, con
WerfF, H. Van DER \& H.G. Richter, 1996. Toward an improved classification of Lauraceae. Annals of the Missouri Botanical Garden 83: 409-418.

ruta paralela a éstas y que no llegan a la margen. Pueden ser simples o compuestas. Son exmediales aquellas con orientación del eje al margen de la hoja y admediales aquellas con orientación de la margen al eje de la hoja.

Nervaduras terciarias: las que surgen de las secundarias y tienen un diámetro más pequeño; en este estudio se identificaron dos tipos: alterna-percurrente, definida por la discontinuidad angular de las venas terciarias corriendo por entre las secundarias; opuesto-percurrente con trayectoria paralela entre las venas secundarias adyacentes, sin ramificar.

Para los siguientes términos fueron utilizadas las definiciones básicas establecidas por Hickey (1974), con modificaciones.

Areolas: área más pequeña de la lámina foliar circundada por nervaduras de diferentes órdenes, con al menos dos nervaduras del mismo calibre y con cada nervadura circundante con largo relativamente uniforme.

Vénulas: última nervadura libre contenida dentro de la areola, pudiendo ser simples (no posee ramas) o ramificadas (posee ramas). La vénula es aquí definida como la ultima nervadura libre dentro de la areola.

Recibido: 21.09.10

Aceptado: 28.12.10 